\title{
D’Arco Silvio Avalle, La doppia verità. Fenomenologia ecdotica e lingua letteraria del Medioevo romanzo
}

\section{Walter Meliga}

\section{(2) OpenEdition}

1 Journals

\section{Edizione digitale}

URL: https://journals.openedition.org/studifrancesi/40236

DOI: 10.4000/studifrancesi.40236

ISSN: 2421-5856

\section{Editore}

Rosenberg \& Sellier

\section{Edizione cartacea}

Data di pubblicazione: 1 juillet 2004

Paginazione: 153

ISSN: 0039-2944

\section{Notizia bibliografica digitale}

Walter Meliga, «D'Arco Silvio Avalle, La doppia verità. Fenomenologia ecdotica e lingua letteraria del Medioevo romanzo», Studi Francesi [Online], 142 (XLVIII | I) | 2004, online dal 30 novembre 2015, consultato il 09 septembre 2021. URL: http://journals.openedition.org/studifrancesi/40236 ; DOI: https://doi.org/10.4000/studifrancesi.40236

Questo documento è stato generato automaticamente il 9 septembre 2021.

\section{(c)}

Studi Francesi è distribuita con Licenza Creative Commons Attribuzione - Non commerciale - Non opere derivate 4.0 Internazionale. 


\title{
D’Arco Silvio Avalle, La doppia verità. Fenomenologia ecdotica e lingua letteraria del Medioevo romanzo
}

\author{
Walter Meliga
}

\section{NOTIZIA}

D'ARCO SILVIO AVALLE, La doppia verità. Fenomenologia ecdotica e lingua letteraria del Medioevo romanzo, Firenze, Edizioni del Galluzzo («Archivio romanzo», 1), 2002, pp. 755.

1 Il volume raccoglie una serie di importanti contributi di filologia e critica del testo dell'illustre studioso (scomparso nel 2002). In particolare, la parte II «La tradizione letteraria francese delle origini» comprende lavori di grande interesse, molti dei quali di difficile reperimerito perché usciti in volumi ormai esauriti o in dispense di corsi universitari, dal 1962 al 1970: La lingua e la letteratura francese dei primi secoli (pp. 223-248), I Giuramenti di Strasburgo (pp. 248-298), La Sequenza di Santa Eulalia (pp. 299-329), Il sermone di Valenciennes (pp. 331-368), Il «Sant Lethgier» (pp. 369-439), I vallonismi del «Sant Lethgier» (pp. 441-447), Cultura e lingua francese delle origini nella «Passion» di Clermont-Ferrand (pp. 449-549), Quelques problèmes à résoudre dans la critique textuelle de la «Passion» (pp. 551- 555), La «Vie de Saint Alexis» nella cultura anglo-normanna dell'XI-XII secolo (pp. 557-611), Lo «Sponsus» (pp. 613-677). 